\title{
KINETIC SPEKTROPHOTOMETRIC DETERMINATION OF 2,4-DICHLORPHE- NOXYACETIC ACID BASED ON ITS INHIBITORY EFFECT ON THE OXIDATION OF SULFANILIC ACID BY HYDROGEN PEROXIDE
}

Ana S. Miletić, Emilija T. Pecev-Marinković* Zora M. Grahovac, Snežana S. Mitić, Aleksandra N. Pavlović, Milan B. Stojković

(ORIGINAL SCIENTIFIC PAPER)

University of Niš, Faculty of Sciences and Mathematics, Department of Chemistry, Niš, Serbia UDC 663.813:632.954:543.2

A kinetic spectrophotometric method for measuring 2,4-dichlorphenoxyacetic acid $(2,4-D)$ is described in this study. The proposed method is based on the inhibitory effect of 2,4-D on the oxidation of sulfanilic acid by hydrogen peroxide in the presence of $\mathrm{Co}$ (II) ion, which was monitored at $370 \mathrm{~nm}$. The variables affecting the rate of the reaction were investigated and the optimum conditions were established. 2,4-D can be measured in the range of $0.07-2.35 \mu \mathrm{g} \mathrm{mL}^{-1}$ and from 2.35 to $23.50 \mu \mathrm{g} \mathrm{mL}^{-1}$ with the detection limit of $0.004 \mathrm{gg} \mathrm{mL}^{-1}$. This method was used to determined traces of 2,4-D in baby fruit juices. The HPLC method was used like a comparative method to verify the results. The results obtained by the proposed method were compared with those obtained by HPLC using UV - DAD detection and they showed a good agreement.

\section{Introduction}

Herbicides are widely used for broad-leaved weeds and other vegetation. They are relatively inexpensive and very powerful even at low concentrations. The majority of herbicides are directly applied to soil or sprayed over crop fields and as a consequence of the large production and high stability, they are released directly into the environment. Phenoxyacid herbicides (PAs) have been most widely used for controlling the growth of weed and other vegetation. Therefore, they are extensively applied against grass and broad leaf weeds in many cereal crops. 2,4-Dichlorophenoxyacetic acid $(2,4-D)$ is extensively used as a plant growth regulator for agricultural and nonagricultural purposes. However, it has been proven to be toxic to humans and animals [1,2]. The exposure to 2,4-D is reported to be associated with irritation of the mucous membranes and skin, gastrointestinal symptoms, headache, and possibly polyneuritis.

A number of analytical methods have been reported for determination of phenoxyacid herbicides in different matrices using high-performance liquid chromatography HPLC [3-5], gas chromatography GC-MS [6-11], capillary electrophoresis [12-16] and micellar electrokinetic chromatography [17]. Because of the complex structure of matrix and the presence of pesticides in small quantities, different procedures for extracting and preconcentration of pesticides from samples are needed to develop. So far, a number of classic extraction methods such as liquid-liquid extraction (LLE) [18], solid-phase extraction (SPE) [8], liquid-liquidliquid microextraction (LLLME) $[9,19,20]$, and dispersive liquid-liquid microextraction (DLLME) [21] have been developed for the pretreatment of phenoxyacid herbicides.
Some authors reported a tandem analytical technique method based on liquid-liquid and solid-phase extraction followed by HPLC for 2,4-D determination in paddy field waters [22]. Many reports described determination of 2,4D by HPLC with a diode array detector (DAD) or GC with electron capture detection (ECD)[23]. Prado et al. reported a sensitive electrochemical method on the carbon paste electrode for 2,4-D determination in water samples [24].

The aim of the present study was to develop and validate a sensitive and simple kinetic spectrophotometric method for 2,4-D determination and its application in baby fruit juice applying a pre-separation process.

\section{Experimental}

\section{Apparatus.}

The reaction was monitored spectrophotometrically. The absorbance of the solution was measured at the wavelength of $370 \mathrm{~nm}$. A Perkin-Elmer Lambda UV/Vis spectrophotometer with $10-\mathrm{cm}$ quartz cell pairs connected to a thermostatic bath was used for recording the absorbance. A water bath thermostat ( $\mathrm{n}$-BIOTEK, INC, model NB-301) was employed to control the reaction temperature. A stopwatch was used to record the reaction time. Chromatographic analyses were performed with an Agilent Technologies, Series 1200 liquid chromatograph, equipped- with an Agilent photodiode array detector (DAD), Model 1200 with RFID tracking technology for flow cells and a UV lamp, an automatic injector and Chem Station software. The analytical column was an Agilent - Eclipse XDBC-18 $\mathrm{C}_{18}$ column $(150 \times 4.6 \mathrm{~mm})$.

\footnotetext{
* Author address: Emilija Pecev-Marinković, Faculty of Sciences and Mathematics, Department of Chemistry, Višegradska 33, P.O. Box 224, 18000 Niš, Serbia

E-mail: emapecev@medianis.net, epecev@yahoo.com

The manuscript received: July, 27, 2015.

Paper accepted: September, 09, 2015.
} 
J. T. Baker Model SPE-12 with a vacuum pump was used for the solid phase extraction of the samples.

Model BÜCHI R-200/205 rotary vacuum evaporator including B-490 bath with a vacuum pump was used to evaporate the extracts.

\section{Reagents}

2,4-dichlorphenoxyacetic acid standard was obtained from Dr Ehrenstorfer (Germany) with a certified purity of $99 \%$. A $4 \times 10^{-2} \mathrm{molL}^{-1}$ solution of the substrate sulfanilic acid (SA) (Merck) was prepared by dissolving $0.3463 \mathrm{~g}$ of SA in $50 \mathrm{~mL}$ of water. The initial $2 \mathrm{~mol} \mathrm{~L}^{-1}$ solution of hydrogen peroxide was prepared from $30 \% \mathrm{H}_{2} \mathrm{O}_{2}$ (Merck), and its exact concentration was standardized permanganometrically. Because of their limited stability, it was prepared just before use. A $0.01 \mathrm{~mol} \mathrm{~L}^{-1}$ stock solution of $\mathrm{Co}^{2+}$ was prepared by dissolving the accurately weighed mass $\mathrm{CoCl}_{2} \cdot 2 \mathrm{H}_{2} \mathrm{O}$ (Merck) in $100 \mathrm{~mL}$ of water. Its exact concentration was controlled complexometrically. Universal buffers [25] were obtained by mixing the solutions of $\mathrm{CH}_{3} \mathrm{COOH}\left(0.4 \mathrm{~mol} \mathrm{~L}^{-1}\right)$, $\mathrm{H}_{3} \mathrm{PO}_{4}\left(0.4 \mathrm{~mol} \mathrm{~L}^{-1}\right), \mathrm{H}_{3} \mathrm{BO}_{3}\left(0.4 \mathrm{~mol} \mathrm{~L}^{-1}\right)$ with $\mathrm{NaOH}(0.1 \mathrm{~mol}$ $\left.\mathrm{L}^{-1}\right)$. HPLC grade methanol $(\mathrm{MeOH})$ and acetonitrile $(\mathrm{ACN})$ were obtained from Baker (UK). Analytical grade chemicals and deionized water with conductivity of $0.05 \mu \mathrm{S} \mathrm{cm}^{-1}$ (MicroMed high purity water system TKA Wasseraufbereitungssysteme $\mathrm{GmbH}$ ) were used for the preparation of all solutions.

\section{Kinetic Procedure}

In a fourth-compartment reaction vessel, $1 \mathrm{~mL}$ of $\mathrm{SA}$ (0.04 mol L-1) in the first compartment, $1 \mathrm{~mL} \mathrm{H}_{2} \mathrm{O}_{2}(2.0 \mathrm{~mol}$ $\left.\mathrm{L}^{-1}\right)$ in the second, $5 \mathrm{~mL}$ universal buffer $\left(\mathrm{pH}^{2}\right.$ 9.66) in the third, $0.2 \mathrm{~mL} \mathrm{Co}^{2+}\left(1 \cdot 10^{-3} \mathrm{~mol} \mathrm{~L}^{-1}\right)$ and $1 \mathrm{~mL} 2,4-\mathrm{D}(235 \mu \mathrm{g}$ $\left.\mathrm{mL}^{-1}\right)$ in the fourth compartment were measured and demineralized water up to the total volume of $10 \mathrm{~mL}$ was added and the vessel was immerged in a $25^{\circ} \mathrm{C}$ water bath. After the components had been brought to the reaction temperature and mixed by vigorous shaking, the reaction mixture was transferred into a $10-\mathrm{cm}$ temperature controlled cell in the spectrophotometer. The change in absorbance (A) at $370 \mathrm{~nm}$ as a function of time $(\mathrm{t})$ was measured every $30 \mathrm{sec}$. over a period of $6 \mathrm{~min}$. The initial rate of the reaction at different concentrations of each of the reactants was obtained by measuring the slope of the linear part of the kinetic curves to the absorbance-time plot: from Beer's law $\mathrm{A}=\varepsilon \cdot|\cdot \mathrm{c} ; \mathrm{dA} / \mathrm{dt}=\varepsilon \bullet| \cdot(\mathrm{dc} / \mathrm{dt}) ;$ slope $=\mathrm{dA} / \mathrm{dt} ;$ rate $=\mathrm{dc} / \mathrm{dt}$; $\mathrm{dc} / \mathrm{dt}=(\mathrm{dA} / \mathrm{dt}) / \varepsilon \bullet$. The calibration graph was constructed by plotting the slope of the linear part of the kinetic curve, versus concentration of 2,4-D $\left(\mathrm{C}_{2,4-\mathrm{D}}, \mathrm{\mu g} \mathrm{mL}^{-1}\right)$.

\section{Analysis of the fruit juice samples}

Commercially available apple, grape, plum, peach, black currant, carrot and pear juices were used to confirm the applicability of the analytical method. For the real sample analysis, fruit juice samples used for recovery studies were previously tested and proven to be free from the pesticide considered. Baby fruit juices of different brands produced by different domestic companies were purchased in local supermarkets. All juice samples were preserved at $4^{\circ} \mathrm{C}$.

Spiked juice samples for recovery determination were prepared by the addition of the appropriate amount of a standard stock solution of determined 2,4-D (235 $\left.\mu \mathrm{g} \mathrm{mL}^{-1}\right)$ and left to stay for 1 day. In $50 \mathrm{~mL}$ of the juice sample a $20 \mathrm{~mL}$ volume of $\mathrm{ACN}$ was added, and the mixture was homogenized for $1 \mathrm{~min}$, after centrifuging at $4000 \mathrm{rpm}$ for $5 \mathrm{~min}$. The organic phase was decanted into a graduated flask, and the mixture was then transferred into a SPE tube. SPE Chromabond $®$ with HR-P cartridge was used for extraction of 2,4-D. Each sample solution was poured into a Chromabond HR-P cartridge (sorbent mass 200 mg Macherey-Nagel, Germany) which had been conditioned. The column was eluted with $5 \mathrm{~mL}$ of $\mathrm{MeOH}$ and $5 \mathrm{~mL} \mathrm{HO}$, then water was filtered through the column, and the column was dried for 30 min under the gentle nitrogen steam. The sample was eluted with $2 \times 5 \mathrm{~cm}^{3} \mathrm{MeOH}$ and then the extract was collected and evaporated at $60{ }^{\circ} \mathrm{C}$ in a rotary vacuum evaporator till dryness. The residue was dissolved with $\mathrm{ACN}$ and transferred into the volumetric flask $(10 \mathrm{~mL})$, and made up with mobile phase $\left(\mathrm{ACN}-\mathrm{H}_{2} \mathrm{O} 75: 25, \mathrm{v} / \mathrm{v}\right)$ to a final volume of $10 \mathrm{~mL}$. The equivalent of $10 \mu \mathrm{L}$ was injected into the HPLC system. The mobile phase for HPLC method consisted of $\mathrm{ACN}-\mathrm{H}_{2} \mathrm{O}(75: 25, \mathrm{v} / \mathrm{v})$ and the flow rate was 1 $\mathrm{mL}$ min $^{-1}$ For kinetic determination $10 \mathrm{~mL}$ of this solution was taken and evaporated at the temperature of $60{ }^{\circ} \mathrm{C}$ till dryness. The residue was dissolved in $\mathrm{MeOH}$, transferred in a $(10 \mathrm{~mL})$ volumetric flask which was filled up with water to obtain the solution with the 2,4-D concentration of $235 \mu \mathrm{g} \mathrm{mL}$. This solution was reconstructed and used for kinetic determination. For recovery studies, fortified fruit juice samples were prepared by spiking with the composite standard solution of pesticide to produce the samples containing pesticide at the concentration ranging from 0.07 to $23.50 \mu \mathrm{g} \mathrm{mL}$. Free samples were kept overnight at room temperature.

\section{Results and discussion}

During the oxidation of SA by hydrogen peroxide in the presence of $\mathrm{Co}^{2+}$ as a catalyst, a yellow colored reaction product was yielded which exhibits an absorption maximum at $370 \mathrm{~nm}$. In the presence of small amounts of 2,4$D$ in the system, the reaction was inhibited. The influence of the reaction variables (reagent concentrations, acidity) on reaction rates was studied to establish optimum reaction conditions. The system was optimized by altering each variable in turn, while the others were kept constant.

For the determination of 2,4-D in the concentration interval studied, the tangent method was chosen. The rate of the reaction was obtained by measuring the slope of the linear part of the kinetic curves of the Absorbance-time plot (slope $=\mathrm{dA} / \mathrm{dt}$ ). The effect of the acidity on the catalytic and inhibited reactions was studied (Fig.1.). The $\mathrm{pH}$ was studied in the interval from 5.33 to 10.00 . For further work a pH of 9.66 was selected. The effect of $\mathrm{H}_{2} \mathrm{O}_{2}$ on the rates of reactions was studied in the range of $0.08-0.28 \mathrm{~mol} \mathrm{~L}^{-1}$. The $\mathrm{H}_{2} \mathrm{O}_{2}$ concentration of $0.25 \mathrm{~mol} \mathrm{~L}^{-1}$ was chosen as optimal 
(Fig.2.). The effect of the SA concentration was studied in the interval $0.8 \times 10^{-3}-5.6 \times 10^{-3} \mathrm{~mol} \mathrm{~L}^{-1}$. For further work, the concentration of $4.0 \times 10^{-3} \mathrm{~mol} \mathrm{~L}^{-1}$ was chosen (Fig.3). The influence of the $\mathrm{Co}^{2+}$ concentration on the catalyzed and inhibited reactions was examined in the range of $0.5 \times 10^{-5}$ $3 \times 10^{-5} \mathrm{~mol} \mathrm{~L}^{-1}$. The concentration of $2 \cdot 10^{-5} \mathrm{~mol} / \mathrm{dm}^{3}$ was chosen like an optimal (Fig.4).

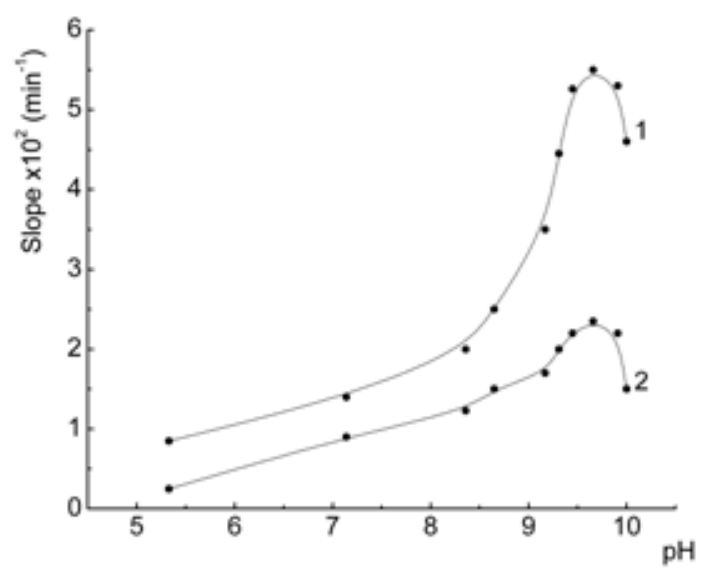

Figure 1. Dependence of the reaction rate on $\mathrm{pH}$ for the catalyzed (1) and inhibited (2) reaction. Initial concentrations: c(SA) $=4 \times 10^{-3} \mathrm{~mol} \mathrm{~L}^{-1} ; \mathrm{c}\left(\mathrm{H}_{2} \mathrm{O}_{2}\right)=0.2 \mathrm{~mol} \mathrm{~L}^{-1} ; \mathrm{c}\left(\mathrm{Co}^{2+}\right)=2 \times 10^{-5} \mathrm{~mol} \mathrm{~L}^{-1}$; $\mathrm{c}(2,4-\mathrm{D})=23.50 \mu \mathrm{g} \mathrm{mL}^{-1} ; \mathrm{t}=25.0 \pm 0.1^{\circ} \mathrm{C}$.

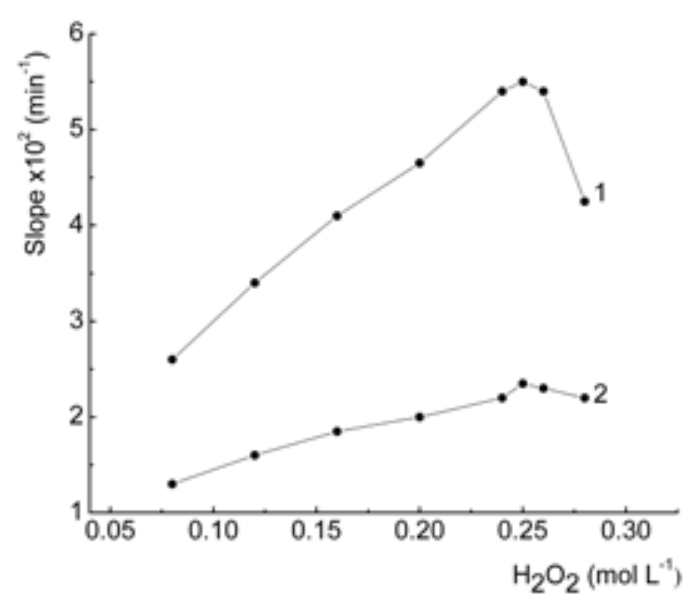

Figure 2. Dependence of the reaction rate on the $\mathrm{H}_{2} \mathrm{O}_{2}$ concentration for the catalyzed (1) and inhibited (2) reaction. Initial concentrations: $\mathrm{pH}=9.66 ; \mathrm{c}(\mathrm{SA})=4 \times 10^{-3} \mathrm{~mol} \mathrm{~L}^{-1} ; \mathrm{c}\left(\mathrm{Co}^{2+}\right)=$ $2 \times 10^{-5} \mathrm{~mol} \mathrm{~L}^{-1} ; \mathrm{c}(2,4-\mathrm{D})=23.50 \mu \mathrm{g} \mathrm{mL}^{-1} ; \mathrm{t}=25.0 \pm 0.1^{\circ} \mathrm{C}$.

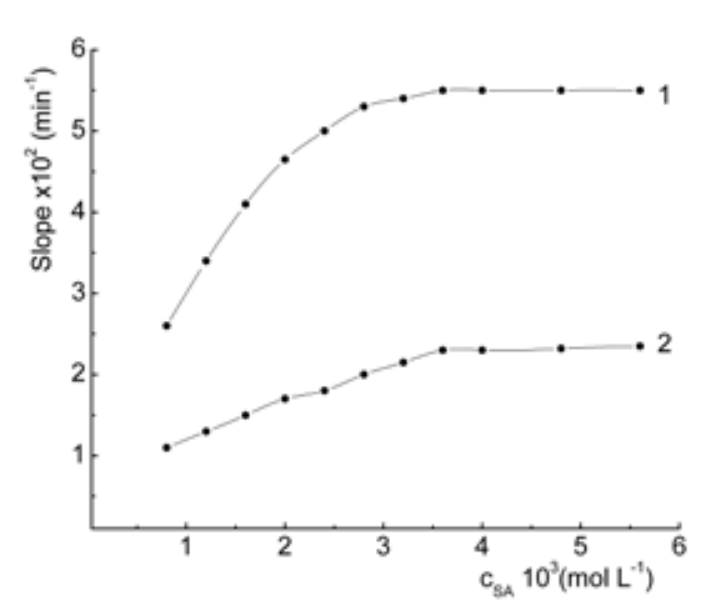

Figure 3. Dependence of the reaction rate on the SA concentration for the catalyzed (1) and inhibited (2) reaction. Initial concentrations: $\mathrm{pH}=9.66 ; \mathrm{c}\left(\mathrm{H}_{2} \mathrm{O}_{2}\right)=0.25 \mathrm{~mol} \mathrm{~L}^{-1} ; \mathrm{c}\left(\mathrm{Co}^{2+}\right)=$ $2 \times 10^{-5} \mathrm{~mol} \mathrm{~L}^{-1} ; \mathrm{c}(2,4-\mathrm{D})=23.50 \mu \mathrm{g} \mathrm{mL}^{-1} ; \mathrm{t}=25.0 \pm 0.1^{\circ} \mathrm{C}$.

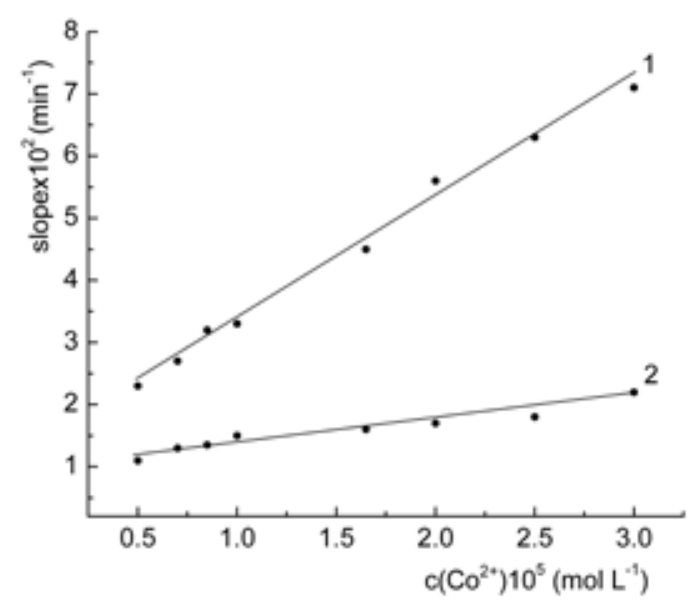

Figure 4. Dependence of the reaction rate on the $\mathrm{Co}^{2+}$ concentration for the catalyzed (1) and inhibited (2) reaction. Initial concentrations: $\left.\mathrm{pH}=9.66 ; \mathrm{c}_{2} \mathrm{H}_{2} \mathrm{O}_{2}\right)=0.25 \mathrm{~mol} \mathrm{~L}^{-1} ; \mathrm{c}(\mathrm{SA})=$ $4 \times 10^{-3} \mathrm{~mol} \mathrm{~L}^{-1} ; \mathrm{c}(2,4-\mathrm{D})=23.50 \mu \mathrm{g} \mathrm{mL}^{-1} ; \mathrm{t}=25.0 \pm 0.1^{\circ} \mathrm{C}$.

Figure 5 shows the calibration curve at the temperature of $25 \pm 0.1^{\circ} \mathrm{C}$. It can be used for the determination of the 2,4-D concentration in the interval of 0.07 to $2.35 \mu \mathrm{g}$ $\mathrm{mL}^{-1}$. The least squares equation $(\mathrm{y}=\mathrm{bx}+\mathrm{a}$, where $\mathrm{b}$ and a are the slope and intercept, respectively) for the calibration graph and correlation coefficient [26] $r$ for the determination of $2,4-\mathrm{D} \mu \mathrm{g} \mathrm{mL}-1$ in the interval from 0.07 to $2.35 \mu \mathrm{g} \mathrm{mL}^{-1}$ and from 2.35 to $23.5 \mu \mathrm{g} \mathrm{mL}^{-1}$ under the optimal reaction conditions were calculated:

$$
\begin{aligned}
& \text { Slope } \cdot 10^{2}=-0.069 \cdot c(2,4-D)+3.92 \quad r=-0.9964 \ldots \\
& \text { Slope } \cdot 10^{2}=-0.52 \cdot(c 2,4-D)+4.92 \quad r=-0.9934 \ldots \ldots .
\end{aligned}
$$


where slope is the slope of the linear part of the kinetic curve to the absorbance-time plot (slope $=\mathrm{dA} / \mathrm{dt}=\varepsilon \cdot \mid \cdot d c /$ $\mathrm{dt}$, Beer's law) and $\mathrm{C}_{2,4-\mathrm{D}}$ is the 2,4-dichlorphenoxyacetic acid concentration expressed in $\mu \mathrm{g} \mathrm{mL}^{-1}$.

On the basis of the results of this kinetic investigations the kinetic equations was formulated in analyzed concentration range of the reactants of the examined reaction systems

Rate $_{I}=k \cdot c_{H^{+}}^{-0.9} \cdot c_{\mathrm{H}_{2} \mathrm{O}_{2}} \cdot c_{\mathrm{Co}(I I)}$

Rate $_{I I}=k_{1} \cdot c_{H^{+}}^{-0.5} \cdot c_{H_{2} O_{2}} \cdot c_{C o(I I)} \cdot c_{2,4-D}^{-1}$

where $\mathrm{k}$ and $\mathrm{k}_{1}$ are the rate constant of the catalyzed and inhibited reaction.

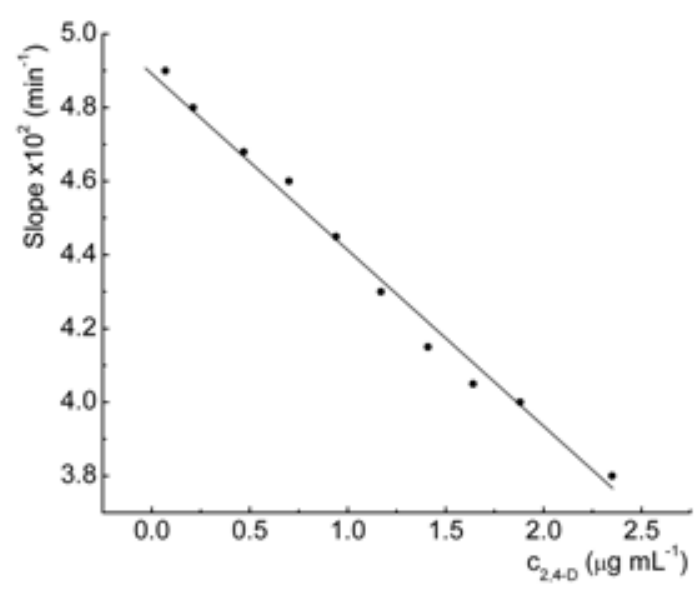

Figure 5. Dependence of the reaction rate on the 2,4-D concentration in the interval $0.07-2.35 \mu \mathrm{g} \mathrm{mL}^{-1}$. Initial concentrations: $\mathrm{pH}=9.66 ; \mathrm{c}\left(\mathrm{H}_{2} \mathrm{O}_{2}\right)=0.25 \mathrm{~mol} \mathrm{~L}^{-1} ; \mathrm{c}(\mathrm{SA})=4 \times 10^{-3} \mathrm{~mol} \mathrm{~L}^{-1}$; $\mathrm{c}\left(\mathrm{Co}^{2+}\right)=2 \times 10^{-5} \mathrm{~mol} \mathrm{~L}^{-1} ; \mathrm{t}=25.0 \pm 0.1{ }^{\circ} \mathrm{C}$.

Quantitative parameters of the analysis are given in Table 1.

Table 1. Quantitative parameters of the analysis

\begin{tabular}{ll}
\hline Calibration range, $\mu \mathrm{g} \mathrm{mL}^{-1}$ & $0.07-2.35 \quad \mathrm{n}=10$ \\
Regression equation & Slope $\cdot 10^{2}=-0.0695 \cdot 10^{2} \cdot \mathrm{C}_{2,4-\mathrm{D}}+3.92 \cdot 10^{2}$ \\
Slope $\pm \mathrm{SD}$ & $\left(-0.0695 \pm 0.044 \cdot 10^{-2}\right) \cdot 10^{-2}$ \\
Intercept $\pm \mathrm{SD}$ & $(3.92 \pm 0.03) \cdot 10^{-2}$ \\
Correlation coefficient, $r$ & -0.9934 \\
Variance, & $1.967 \cdot 10^{-7}$ \\
Detection limit, $\mu \mathrm{g} \mathrm{mL}^{-1}$ & 0.004 \\
Quantification limit, $\mu \mathrm{g} \mathrm{mL}^{-1}$ & 0.013 \\
\hline
\end{tabular}

The limit of detection (LOD) and quantification (LOQ) [27-29] are $0.004 \mu \mathrm{g} \mathrm{mL}-1$ and $0.013 \mu \mathrm{g} \mathrm{mL}^{-1}$, respectively.

The precision and accuracy of the system were studied by performing the experiment 5 times for different concentrations of 2,4-D, and the obtained results are presented in Table 2.
Table 2. Accuracy and precision of the 2,4-D determination

\begin{tabular}{|c|c|c|c|c|c|c|}
\hline $\begin{array}{c}\text { Taken } \\
\left(\mu \mathrm{mL}^{-1}\right)\end{array}$ & $\begin{array}{c}\text { Found }^{\mathrm{a}} \\
\pm \mathrm{SD} \\
\left(\mu \mathrm{gL}^{-1}\right)\end{array}$ & $n$ & $\begin{array}{l}\text { RSD } \\
(\%)^{b}\end{array}$ & $\begin{array}{c}G \\
(\%)\end{array}$ & $\begin{array}{c}\left(\left(\begin{array}{c}-\mu) / \mu \\
)\end{array}\right) \cdot 100\right. \\
(\%)^{c}\end{array}$ & $\begin{array}{c}\text { Recovery } \\
(\%)\end{array}$ \\
\hline 0.07 & $0.067 \pm 0.01$ & & 3.41 & 7.34 & 4.28 & 95.71 \\
\hline 1.17 & $1.12 \pm 0.02$ & 5 & 2.16 & 2.70 & 3.84 & 96.15 \\
\hline 2.35 & $2.31 \pm 0.01$ & & 1.20 & 1.35 & 1.70 & 98.29 \\
\hline
\end{tabular}

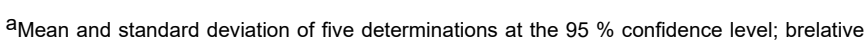
standard deviation; G- relative error; caccuracy of the method

\section{Interference studies}

To study the selectivity of the method, the effects of various species on the determination of 2,4-D at the concentration of $14.10 \mu \mathrm{g} \mathrm{mL}^{-1}$ was studied. The tolerable concentration of each foreign ion was taken as the highest concentration causing an error of less than $\pm 5 \%$. lons like $\mathrm{Fe}^{2+}, \mathrm{Fe}^{3+}$ and $\mathrm{Cu}^{2+}$ interfere in all concentrations. Ions like $\mathrm{Zn}^{2+}, \mathrm{Mn}^{2+}$ and $\mathrm{Ni}^{2+}$ do not interfere when their concentration is the same as the concentration of 2,4-D.Other investigated anions and cations do not have influence the reaction rate of 2,4-D determination.

Applicability of the proposed method

The proposed method was applied to the determination of 2,4-D in baby fruit juices using the direct calibration curve. They were treated as described in Experimental section. The HPLC method was used like a comparative and reliable method to verify the results of the kinetic method. The results of the proposed method were statistically compared with those of the comparative method using a point hypothesis test. As it can be seen in Table 3, the results obtained for the kinetic method are in accordance with the HPLC method. Table 3 shows that $\mathrm{F}$ and $\mathrm{t}$ values at $95 \%$ confidence level are less than the theoretical ones, confirming no significant differences between the performance of the kinetic and HPLC method. Both, recovery percentages and relative standard deviations (RSD) were satisfactory and indicated good performance of the proposed method for the analysis 2,4-D in baby fruit juice.

Figure 6 shows the chromatogram for 2,4-D determination in spiked baby fruit juice sample for its concentration of $2.25 \mu \mathrm{g} \mathrm{mL}^{-1}$ under optimum conditions (ACNwater, 75:25, v/v; at the flow rate of $1 \mathrm{~mL} \mathrm{~min}^{-1}$, and the wavelength of $228 \mathrm{~nm}$ ). The results of the proposed method were statistically compared with those of the parallel HPLC method using a point hypothesis test [30]. 
Table 3. Determination of 2,4-D in baby fruit juice by kinetic method and HPLC method

\begin{tabular}{|c|c|c|c|c|c|c|c|c|}
\hline \multirow[b]{3}{*}{ 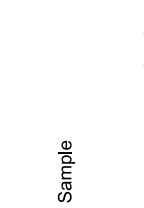 } & \multicolumn{8}{|c|}{$2,4-\mathrm{D}\left(\mu \mathrm{g} \mathrm{mL}^{-1}\right)$} \\
\hline & \multicolumn{8}{|c|}{ Found 2,4-D } \\
\hline & $\begin{array}{c}\text { Spiked } \\
\text { concentration } \\
\left(\mu \mathrm{gL}^{-1}\right)\end{array}$ & $\begin{array}{l}\text { Kinetic } \\
\text { method } \\
\left(\mu \mathrm{g} \mathrm{mL}^{-1}\right)\end{array}$ & $\begin{array}{c}\text { Recovery } \\
(\%)\end{array}$ & $\begin{array}{l}\text { RSD } \\
(\%)\end{array}$ & $\begin{array}{l}\text { HPLC } \\
\text { method } \\
\left(\mu \mathrm{gL}^{-1}\right)\end{array}$ & $\begin{array}{c}\text { Recovery } \\
(\%)\end{array}$ & $\begin{array}{c}\mathrm{t} \\
\text { value }\end{array}$ & $\begin{array}{c}\mathrm{F} \\
\text { value }\end{array}$ \\
\hline $\begin{array}{l}\text { Bebavita } \\
\text { traube }\end{array}$ & 1.22 & $1.18 \pm 0.02$ & 95.90 & 1.03 & 1.175 & 96.33 & 1.75 & 5.69 \\
\hline $\begin{array}{l}\text { Bio juice Hipp } \\
\text { (apples,grapes) }\end{array}$ & 1.28 & $1.26 \pm 0.02$ & 98.43 & 6.51 & 1.256 & 98.12 & 2.02 & 4.63 \\
\hline $\begin{array}{l}\text { Bio Nectar } \\
\text { Hipp (plum) }\end{array}$ & 8.60 & $8.58 \pm 0.02$ & 99.76 & 0.35 & 8.65 & 100.93 & 0.96 & 2.98 \\
\hline $\begin{array}{l}\text { Bio juice Hipp } \\
\text { (carrots) }\end{array}$ & 1.17 & $1.136 \pm 0.01$ & 97.10 & 1.72 & 1.14 & 97.43 & 1.64 & 3.25 \\
\hline $\begin{array}{l}\text { Frutek } \\
\text { (peach) }\end{array}$ & 6.52 & $6.22 \pm 0.02$ & 95.33 & 9.19 & 6.41 & 98.32 & 1.15 & 3.98 \\
\hline $\begin{array}{l}\text { Frutek (cherry, } \\
\text { black currant }\end{array}$ & 1.18 & $1.153 \pm 0.01$ & 97.71 & 0.93 & 1.14 & 96.61 & 0.76 & 2.32 \\
\hline $\begin{array}{c}\text { Frutek } \\
\text { (apples,carrots) }\end{array}$ & 7.91 & $4.13 \pm 0.03$ & 99.24 & 0.40 & 7.86 & 98.60 & 1.65 & 2.06 \\
\hline $\begin{array}{l}\text { Bio juice Hipp } \\
\text { (fruit mixture) }\end{array}$ & 7.11 & $6.65 \pm 0.02$ & 93.53 & 2.25 & 6.58 & 92.54 & 2.23 & 1.66 \\
\hline $\begin{array}{l}\text { Bebivita Milder } \\
\text { Apfelsaft }\end{array}$ & 3.12 & $2.85 \pm 0.01$ & 91.34 & 4.91 & 2.92 & 93.58 & 1.29 & 3.68 \\
\hline $\begin{array}{l}\text { Bio juice Hipp } \\
\text { (red fruits } \\
\text { mixture) }\end{array}$ & 2.25 & $2.16 \pm 0.02$ & 96.00 & 2.68 & 2.20 & 97.77 & 1.69 & 2.63 \\
\hline $\begin{array}{l}\text { Frutek (plums, } \\
\text { apples, pears) }\end{array}$ & 1.32 & $1.26 \pm 0.02$ & 95.45 & 1.35 & 1.23 & 93.18 & 1.96 & 3.44 \\
\hline Frutek (apples) & 0.96 & $0.87 \pm 0.01$ & 90.62 & 1.22 & 0.86 & 89.58 & 0.39 & 1.68 \\
\hline $\begin{array}{l}\text { Hipp (pear in } \\
\text { apple juice) }\end{array}$ & 2.15 & $2.22 \pm 0.02$ & 103.25 & 1.65 & 2.19 & 101.86 & 0.72 & 1.96 \\
\hline $\begin{array}{l}\text { Frutek(grapes, } \\
\text { apples) }\end{array}$ & 1.53 & $1.48 \pm 0.01$ & 96.73 & 0.83 & 1.46 & 95.42 & 1.22 & 3.47 \\
\hline Frutek (pears) & 4.96 & $4.82 \pm 0.01$ & 97.98 & 0.36 & 4.89 & 98.58 & 0.86 & 1.29 \\
\hline
\end{tabular}

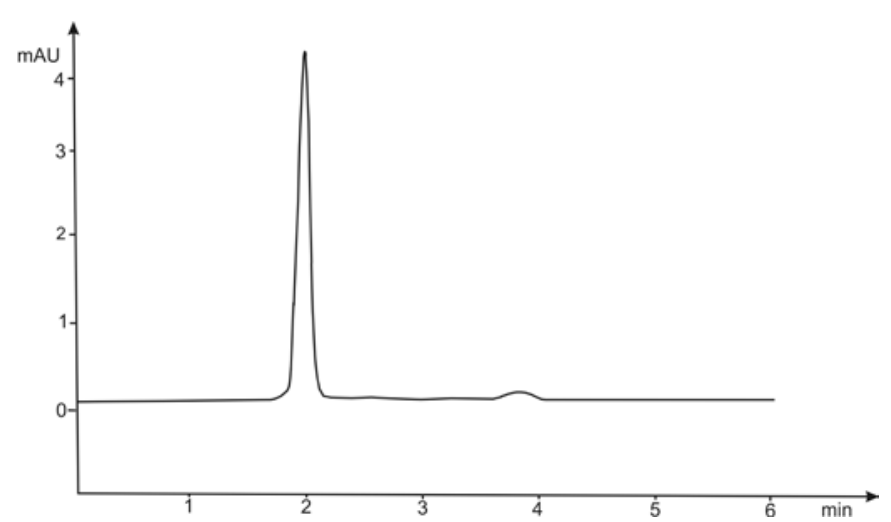

Figure 6. HPLC chromatogram of spiked fruit juice sample with $2.25 \mu \mathrm{g} \mathrm{mL}^{-1}$ 2,4-D. Column C18 (Zorbax, $5 \mu \mathrm{m}, 150 \mathrm{~mm} \times 4.6 \mathrm{~mm}$ ). Mobile phase: ACN-water, 75:25 (v/v); at a flow rate of $1 \mathrm{~mL} \mathrm{~min}^{-1}$. Detection: spectrophotometer at $228 \mathrm{~nm}$

\section{Conclusion}

The inhibited effect of 2,4-dichlorphenoxyacetic acid of the oxidation of SA with hydrogen peroxide in the presence of $\mathrm{Co}^{2+}$ ion was investigated. This kinetic-spectrophotometric method can be used for 2,4-D determination in the range of $0.07-23.50 \mu \mathrm{g} \mathrm{mL}^{-1}$. The proposed method is highly sensitive and simple, and the precision is very acceptable for the determination of low ranges of 2,4-D. The kinetic-spectrophotometric method reported in this paper is simple, rapid and inexpensive and thus very appropriate for the routine quality control analysis of this herbicide in the real samples. The proposed method was successfully applied for determination of 2,4-D in baby fruit juices with the recovery of $89.58-100.93 \%$. A statistical comparison of the results with parallel HPLC method showed good agreement and indicates no significant difference in accuracy and precision.

\section{Acknowledgement}

This research was supported by the Serbian Ministry of Education and Sciences, the Republic of Serbia, grant number 172061 . The authors are grateful for the financial support provided by the Ministry.

\section{References}

[1] D. H. Garabrant, M. A. Philbert, Review of 2,4-dichlorophenoxyacetic acid (2,4-D) epidemiology and toxicology, Critical Reviews in Toxicology, 32(4) (2002) 233-257.

[2] S. B. James, E. H. Larry, Regulatory progress, toxicology, and public concerns with 2,4-D: Where do we stand aftertwo decades?, Crop Protection, 26 (2007) 266-269.

[3] S.M. Waliszewski, V.T. Pardo Sedas, The Use of Silar $10 \mathrm{CP}$ for the Packed Column Gas Chromatographic Determination of Chlorophenoxyacetic Acid Herbicides in Water and Sediments, Int. J. Environ.Anal.Chem.,49 (1992)231-238.

[4] L. Chiang, R.J. Magee, B.D. James, Chromatographic determination of chlorinated phenoxyacetic acids by simultaneous extraction-methylation and application to soil analysis, Anal. Chim. Acta, 255 (1991) 187-196.

[5] C. Orapin, P. Sumate, N. Athapol, M. S. Roger, Superheated water extraction and phase transfer methylation of phenoxy acid herbicides from solid matrices, J. Chromatogr. A, 1152 (2007) 268 -273.

[6] I.S. Kim, F.I. Sasinos, R.D. Stephens, J. Wang, M.A. Brown, Determination of chlorinated phenoxy acid and ester herbicides in soil and water by liquid chromatography particle beam mass spectrometry and ultraviolet absorption spectrophotometry, Anal. Chem., 63 (1991) $819-823$

[7] N. Rosales-Conrado, M.E. Leon-Gonzalez, L.V. PerezArribas, L.M. Polo-Diez, Determination of chlorophenoxy acid herbicides and their esters in soil by capillary high performance liquid chromatography with ultraviolet detection, using large volume injection and temperature gradient,Anal. Chim. Acta, 470 (2002) 147-154.

[8] N. Rosales-Conrado, M.E. Leon-Gonzalez, L.V. PerezArribas, L.M. Polo-Diez, Capillary liquid chromatography of chlorophenoxy acid herbicides and their esters in apple juice samples after preconcentration on a cation exchanger based on polydivinylbenzene- $\mathrm{N}$-vinylpyrrolidone $\mathrm{J}$. Chromatogr. A, 1076 (2005) 202-206.

[9] C.C. Chen, M.B. Melwanki, S.D. Huang, Liquid-liquidliquid microextraction with automated movement of 
the acceptor and the donor phase for the extraction of phenoxyacetic acids prior to liquid chromatography detection, J. Chromatogr. A, 1104 (2006) 33-39.

[10] J.F. Liu, L.Torang, P. Mayer, J.A. Jonsson, Passive extraction and clean-up of phenoxy acid herbicides in samples from a groundwater plume using hollow fiber supported liquid membranes, J. Chromatogr. A 1160 (2007) 56-63.

[11] D. L. Hughes, D. J. Ritter, R. D. Wilson, Determination of 2,4-dichlorophenoxyacetic acid (2,4-D) in human urine with mass selective detection, J Environ Sci Health B, 36(6) (2001) 755-64.

[12] Q. Wu, H.A. Claessens, C.A. Cramers, The separation of herbicides by micellar electrokinetic capillary chromatography,Chromatographia, 34 (1992) 25-30.

[13] F.F. Fu, L.X. Xiao, W. Wang, X.Q. Xu, L.J. Xu, G.M. Qi, G.N. Chen, Study on the degradation of 2,4-dichlorophenoxyacetic acid (2,4-D) and 2-methyl4-chloro-phenoxyacetic sodium (MCPA sodium) in natural agriculture-soils of Fuzhou, China using capillary electrophoresis, Science of the Total Environment, 407 (2009) 1998-2003.

[14] J.H. Li, Z.W. Cai, Stacking and separation of urinary porphyrins in capillary electrophoresis: Optimization of concentration efficiency and resolution, Talanta, 77 (2008) 331-339.

[15] J.H. Li, W. Chan, Z.W. Cai, On-line capillary electrophoresiselectrospray ionization mass spectrometry analysis of urinary porphyrins, Electrophoresis, 30 (2009) 1790-1797.

[16] Y.Y. Wen, J.H. Li, J.P. Ma, L.X. Chen, Recent advances in enrichment techniques for trace analysis in capillary elect rophoresis,Electrophoresis, 33 (2012) 2933-2952.

[17] Y. Ma, Y. Wen, J. Li, H. Wang, Y. Ding, L. Chen, Determination of three phenoxyacid herbicides in environmental water samples by the application of dispersive liquid-liquid microextraction coupled with micellar electrokinetic chromatography, Cent. Eur. J. Chem., 11(3) (2013) 394-403.

[18] M. Hiemstra, A. deKok, Comprehensive multi-residue method for the target analysis of pesticides in crops using liquid chromatography-tandem mass spectrometry, J. Chromatogr. A, 1154 (2007) 3-25.
[19] M.B. Melwanki, S.D. Huang, Three-phase system in solvent bar microextraction: An approach for the sample preparation of ionizable organic compounds prior to liquid chromatography,Anal. Chim. Acta, 555 (2006) 139-145.

[20] J. Wu, K.H. Ee, H.K. Lee, Automated dynamic liquid-liquidliquid microextraction followed by high-performance liquid chromatography-ultraviolet detection for the determination of phenoxy acid herbicides in environmental waters,J. Chromatogr. A, 1082 (2005) 121-127.

[21] K. Farhadi, A.A. Matin, P. Hashemi, LC Determination of Trace Amounts of Phenoxyacetic Acid Herbicides in Water after Dispersive Liquid-Liquid Microextraction, Chromatographia, 69 (2009) 45-49.

[22] J.Y. Park, J. H. Choi, A. M. Abd El-Aty, B. M. Kim, J.H Park, W.J. Choi, J.H. Shim, Development and validation of an analytical method for determination of endocrine disruptor, 2,4-D, in paddy field water, Biomed Chromatogr., 25(9) (2011)1018-24.

[23] C. Aprea, G. Sciarra, N. Bozzi, L. Lunghini, Analysis of 2,4-Dichlorophenoxyacetic Acid and 2-Methyl-4Chloro-Phenoxyacetic Acid in Human Urine, Methods in Biotechnology, 19 (2005) 91-103.

[24] A. G. S. Prado, H. T. Barcelos, A. O. Moura, A. R. Nunes, E. S. Gil, Dichlorophenoxyacetic Acid Anchored on SilicaGel Modified Carbon Paste for the Determination of Pesticide 2,4-D, Int. J. Electrochem. Sci., 7 (2012) 8929 $-8939$.

[25] Yu. Yu. Luruye: Spravochnik po Analiticheskoi Khimii, Khimia, Moskva, 1989, p. 256.

[26] J.N. Miller, Basic and statistical methods for analytical chemistry. Part 2. Calibration and regression methods, Analyst, 116 (1991)3-14.

[27] H. A. Motolla, Kinetic Aspect of Analytical Chemistry, Wiley, New York, 1998.

[28] J. Ermer, Validation in pharmaceutical analysis. Part I: An integrated approach, J. Pharm. Biomed. Anal., 24 (2001) 755-767.

[29] V. Thomsen, D. Schatzlein, D. Mercuro, Limits of Detection in spectroscopy, Spectroscopy, 18 (2003)112-114.

[30] D. A. Skoog, D. M. West, F. J. Holler, Fundamentals of Analytical Chemistry, Saunders College Publishing, Philadelphia, 1996, p. 51.

Izvod

\section{KINETIČKO SPEKTROFOTOMETRIJSKO ODREĐIVANJE 2,4-DIHLORFENOKSI SIRĆETNE KISELINE NA OSNOVU NJENOG INHIBITORNOG DEJSTVA NA REAKCIJU OKSIDACIJE SULFANILNE KISELINE VODONIK PEROKSIDOM}

Ana S. Miletić, Emilija T. Pecev-Marinković, Zora M. Grahovac, Snežana S. Mitić, Aleksandra N. Pavlović, Milan B. Stojković

Univerzitet u Nišu, Prirodno-matematički fakultet, Departman za hemiju, Niš, Srbija

(ORIGINALNI NAUČNI RAD) UDK 663.813:632.954:543.2

Razvijena je nova kinetičko-spektrofotometrijska metoda za određivanje 2,4-dihlorfenoksi sirćetne kiseline. Metoda se bazira na inhibitornom efektu 2,4-D u reakciji oksidacije sulfanilne kiseline vodonik peroksidom u baznoj sredini u prisustvu Co(II) jona kao katalizatora. Brzina reakcije praćena je spektrofotometrijski na talasnoj dužini od $370 \mathrm{~nm}$. Praćen je uticaj reagenasa na brzinu katalitičke i inhibitorne reakcije i određeni su optimalni eksperimentalni uslovi. Konstruisana je kalibraciona prava za određivanje 2,4-D u intervalu koncentracija od 0,07 - 2,35 $\mu \mathrm{g} \mathrm{mL}^{-1}$ i 2,35 to $23,50 \mu \mathrm{g} \mathrm{mL}-1$. Optimizovanjem uslova metode izračunata je granica detekcije i granica određivanja $0,004 \mu \mathrm{g} \mathrm{mL}^{-1}$ i $0,013 \mu \mathrm{g} \mathrm{mL}^{-1}$. Kinetička metoda je primenjena za određivanje 2,4-D u sokovima za ishranu beba, dok je HPLC metoda korišćena kao uporedna metoda, kako bi se verifikovali rezultati kinetičke metode. Rezultati koji su dobijeni dvema metodama pokazuju dobro slaganje.
Ključne reči: 2,4-dihlorfenoksi sirćetne kiseline; kinetika; sok za bebe; validacija metode 